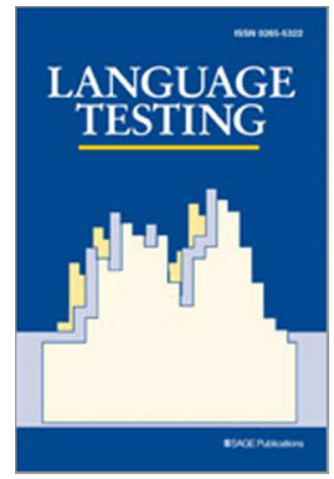

\title{
Language assessment literacy in university admission policies, or the dialogue that isn't.
}

\begin{tabular}{|c|c|}
\hline Journal: & Language Testing \\
\hline Manuscript ID & LT-17-0133.R2 \\
\hline Manuscript Type: & Original Manuscript \\
\hline Keywords: & $\begin{array}{l}\text { language assessment literacy, policy evaluation, university admission, } \\
\text { language policy, qualitative study }\end{array}$ \\
\hline Abstract: & $\begin{array}{l}\text { Research in the field of Language Assessment Literacy (LAL) shows that } \\
\text { university admission officers and policy makers are not generally well- } \\
\text { versed in matters of LAL. Only very few studies date have traced why this } \\
\text { may be the case however, and in the field of language testing few studies } \\
\text { to date have reported on how university admission language requirements } \\
\text { are set. Nevertheless, because of the impact of test use on university } \\
\text { admissions, developing such knowledge is essential to the progress of LAL } \\
\text { as a discipline. This paper reports on a qualitative study that includes all } \\
\text { university admission policy makers in one context (Flanders, Belgium). The } \\
\text { analyses of the interviews show that the concerns and ideas of LAL } \\
\text { scholars and those of university admission policy makers may differ } \\
\text { substantially. Real-world policy is determined by pragmatism and } \\
\text { compromise and policy makers, even at universities, may fail to consider } \\
\text { empirical findings. Because this study shows that the view of policy makers } \\
\text { can be quite dissimilar from the traditional approach taken in the LAL } \\
\text { literature, the authors argue that it may be as beneficial to encourage } \\
\text { policy literacy among language testing professionals, as to expect LAL from } \\
\text { policy makers. }\end{array}$ \\
\hline
\end{tabular}




\title{
Language assessment literacy in university admission policies, or the dialogue that isn't.
}

\begin{abstract}
Research in the field of Language Assessment Literacy (LAL) shows that university admission officers and policy makers are not generally well-versed in matters of LAL. Only very few studies date have traced why this may be the case however, and in the field of language testing few studies to date have reported on how university admission language requirements are set. Nevertheless, because of the impact of test use on university admissions, developing such knowledge is essential to the progress of LAL as a discipline. This paper reports on a qualitative study that includes all university admission policy makers in one context (Flanders, Belgium). The analyses of the interviews show that the concerns and ideas of LAL scholars and those of university admission policy makers may differ substantially. Real-world policy is determined by pragmatism and compromise and policy makers, even at universities, may fail to consider empirical findings. Because this study shows that the view of policy makers can be quite dissimilar from the traditional approach taken in the LAL literature, the authors argue that it may be as beneficial to encourage policy literacy among language testing professionals, as to expect LAL from policy makers.
\end{abstract}

Keywords: language assessment literacy, policy evaluation, university admission, language policy, qualitative study

\section{Language assessment literacy and university admission policies}

As language assessment is being used for a wide range of high-stakes purposes including university admission and citizenship, language testing experts have emphasized the need for increased language assessment literacy (LAL) among score users (Taylor, 2013). Since LAL is a relatively new research field, there is no absolute conceptual consensus among researchers. Most will agree, however, that LAL concerns the assessment-related knowledge, skills, or principles held by those for whom the use or interpretation of language 
assessments is part of their professional responsibility (e.g., Fulcher, 2012; Taylor, 2009, 2013). LAL thus refers to stakeholders' ability to understand, interpret and use the language testing concepts within their specific professional context.

Early LAL research could be perceived as having a somewhat unidirectional approach, premised on the idea that test users should adopt the insights, beliefs and principles of language testers. Perhaps because of this, most LAL research to date has focused on stakeholders' knowledge of language assessment concepts (Baker, 2016), and it has often concluded that stakeholders lack important knowledge to responsibly and adequately select, use or interpret assessments, tests, or their outcomes (Fulcher, 2012; Author, 2013; O’Loughlin, 2011, 2013; Rea-Dickins, Kiely, \& Yu, 2007).

More recent work has adopted a more open and outward-looking stance (InbarLourie, 2017), and LAL proponents have been working to include stakeholder groups during test development (Author, 2013); others have suggested developing LAL profiles for different stakeholders (Taylor, 2013), while still others have proposed drawing up standards that include core assessment skills and knowledge needed by specific groups of test users (Inbar-Lourie, 2008). In line with this trend, Baker (2016) has recently argued for a collaborative attitude, echoing Taylor's warning about avoiding an air of intellectual superiority (Taylor, 2013): "If we as language assessment specialists concentrate on propositional knowledge of our field, we are always the ones with a superior position" (Baker, 2016, p. 81).

In Baker's conceptualization, LAL should consist of propositional, procedural and collaborative knowledge. As such, she stresses not only that LAL involves language assessment knowledge (propositional) and the application of that knowledge (procedural), but also that language testing professionals and stakeholders need to interact in order determine what kind of LAL is needed in a specific context of use. In her state-of-the-art review of LAL research, Inbar-Lourie (2017), also highlighted this collaborative turn, stressing how determining an LAL canon for a specific context needs to rely on negotiation and dialogue with the relevant stakeholders.

The primary focus of LAL research has been on teachers (Fulcher, 2012; InbarLourie, 2017), but considerable attention has also been devoted to law makers (Pill \& Harding, 2013) and university admission officers (Baker, 2016; Baker, Tsushima, \& Wang, 2014; O'Loughlin, 2011, 2013). Most research has focused on the stakeholders who enact policy, but not necessarily on those who construct it (Baker et al., 2014). Nevertheless, understanding the professional context of these policy makers is crucial to an effective 
Policy refers to the rules and measures documented in national and institutional laws and regulations in order to pursue a valued goal or address a problematic situation (Grin, 2003), and to actions taken by key actors in the policy-making process (Ball, Maguire, \& Braun, 2012). As discussed above, LAL research has primarily focused on this last part of this definition - the actions - and less on the first - how regulations are made.

Policy analysis research examines how policy is made. It has convincingly shown that when research fails to consider the real-world context and constraints, policy makers may perceive it as too disconnected from reality to have an impact (Howlett \& Giest, 2013; Jann \& Wegrich, 2007; Wollmann, 2007). Contrary to the classic conceptualization of policy making as a sequence of identifiable stages (Jann \& Wegrich, 2007), recent research has described it as being a patchwork of decisions that are neither cyclical nor linear, logical nor rational (Jann \& Wegrich, 2007; Van den Bosch \& Cantillon, 2006). Real-world policy making may be modified, embraced or abandoned due to a host of external factors, including budget constraints, political compromise, lobby groups, media attention, restrictions imposed by previous policy, and the like (Jann \& Wegrich, 2007). In line with these insights policy analysts have recently proposed communicative, argumentative models of policy evaluation (Fischer, 2007; Lejano, 2007; Vedung, 2013). Much like the evolution in the field of LAL, these new models of policy analysis demand that researchers engage in communication with policy makers, to understand the context in which policy-making takes place, and to remain attentive to the contextual parameters that impact decisions. 
Fischer's argumentative model of policy analysis $(2003,2007)$ has been especially influential in this regard, and could prove useful in the context of evaluating language assessment policies. Based on Toulmin's argument structure (Toulmin, 2003), Fischer's approach consists of four interrelated discourses. The first two levels - program verification and situational validation - are concerned with examining the policy itself. The two final levels of Fischer's model - systems vindication and ideological choice -focus on the impact of policy on society. Table 1 summarizes the focus and the primary purpose of each of these phases.

[Table 1 around here]

The main purpose of this paper is to describe the policy-making processes in one context - university admission in Flanders, Belgium - and discuss them in the light of LAL issues. As such, the authors hope to contribute to the understanding of policy literacy in the LAL debate. The section below introduces the research context.

\section{Policy in practice: the case of Flanders, Belgium}

Policy is made and enacted at different levels, including the national or supranational macro level and the meso level of institutions or organizations (Howlett \& Giest, 2013). Often, educational policy is a combination of both: a regulatory framework is developed at a national level, and individual institutions decide on policy measures within these constraints (Ball et al., 2012). In Europe it is not uncommon for university admission language requirements to rely on national guidelines, which can be refined or adjusted consistent with local needs (Author, 2017). In this study, we will consider the case of Flanders, the northern part of Belgium where Dutch is the only official language. In other parts of the country, French and German are the official languages. In Flanders, university admission language requirements for international L2 (i.e., non-native speakers of Dutch) students are decided at both governmental and at university levels.

It is difficult to estimate exactly how many are impacted by these requirements, since universities are reluctant to share this information publicly. The number of international students in Flanders has been steadily increasing in recent years (Beleidscel Diversiteit en 
Gender, 2016), and this group now accounts for up to $20 \%$ of the population at the five Flemish universities, according to publicly available information (Table 2).

[Table 2 around here]

Since these percentages also include $\mathrm{PhD}$ students who do not need to pass any language requirements, the proportion of undergraduate international L2 students who are required to pass a language test is considerably lower. Few universities are willing to disseminate detailed data about this population alone however. Two universities shared information on condition of anonymity. At one, just $1.7 \%$ of the newly registered freshmen in 2015 were international students (private communication, 6 July 2016), but this number includes Dutch-speaking students from the Netherlands. Another university estimated the proportion of international L2 students relative to the total undergraduate population, at around $4 \%$, but could not provide exact figures (private communication, 8 June 2016).

Although every Flemish institution has a large degree of autonomy, there are clear correspondences between the language requirements across the board. First, it is a legal requirement that most university programs are Dutch-medium: at the bachelor's level, $94 \%$ of the programs must be taught in Dutch only (Vlaamse Regering, 2013). International students who wish to enroll for a Dutch-medium program must demonstrate that they have an adequate level of Dutch. In practice this means that most university programs have a language requirement at B2 of the Common European Framework of Reference for Languages (CEFR - Council of Europe, 2001).

In the CEFR, six levels of L2 profiency are identified, and presented as three dyads, ranging from the beginner level A1 through the advanced C2. In Flanders and throughout Europe, B2 is typically required for university admission (Author, 2018). The B2 level is comparable to ACTFL Advanced Mid (ACTFL, 2016) and refers to an adult L2 learner who can understand the main ideas of complex texts, interact fluently and spontaneously with native speakers, produce clear and detailed texts, and develop a sustained argumentation (Council of Europe, 2001: 24). Table 3 shows how the CEFR levels and sublevels map onto the ACTFL scale.

[Table 3 around here] 
Different universities allow for different kinds of evidence of B2 ability but the documents listed below are accepted at all five institutions (Ghent University, 2016; KU Leuven, 2016; Universiteit Antwerpen, 2016; Universiteit Hasselt, 2016; Vrije Universiteit Brussel, 2014):

- A certificate of STRT or ITNA, two accredited B2 tests;

- Proof of having successfully completed one year at a Dutch-medium secondary school;

- Proof of having attained sixty credits in a Flemish higher education program.

These requirements originate from a Flemish government decree known among policy makers as "the codex" (Vlaamse Regering, 2013). This document stipulates that universities may use the following documents as sufficient evidence for the admission of international L2 students: (1) a language test result (2) proof of having successfully completed one year in a Dutch-medium secondary school, and (3) proof of having achieved 60 credits in a Dutchmedium higher education program (which implies that the student had passed the first or the second requirement when first registering). The codex is non-binding and does not specify a required language level or the tests that are accepted. Since it predates the CEFR and it has not been updated since 1994, it does not contain any reference to CEFR levels. Consequently, universities are free to determine which test they accept, but in practice, all Flemish universities use the B2 level as the default admission requirement, and all accept STRT (Educatief Startbekwaam, or Ready to start higher education) and ITNA (Interuniversitaire Taaltoets Nederlands voor Anderstaligen, or Inter University test of L2 Dutch) as proof of that level. ITNA is a computer-based and face-to-face test, issued and developed by the Interuniversitair Testing Consortium of Flemish university language centers. STRT, a task-based, integrated-skill language test, is the only Dutch language test at the B2 level that is internationally administered. It is developed at the University of Leuven, and funded by the Dutch Language Union, an international, intergovernmental organization overseeing the Dutch language policy in the Netherlands, Belgium and Suriname. The publicly available evidence to support the language admission requirements is limited.

\section{Research questions}

This paper maps the conditions that impact a university admission policy, and investigates to what extent language testing expertise and empirical data have impacted the current policy. 
The first research question consists of two components and is concerned with the general process of policy-making:

RQ1a How is the university admission policy for international L2 students made at governmental level?

RQ1b How is the university admission policy for international L2 students made at institutional level?

The second research question relates to the two policy-focused components of Fischer's model (Program verification, Situational validation):

RQ2a How is policy effectiveness monitored?

$\mathrm{RQ} 2 \mathrm{~b}$ What is the rationale behind the language admission requirements?

Although a great deal of research is conducted on student and instructor beliefs about language admissions policies, relatively little is conducted about administrator beliefs (Hawkey, 2006; Author, 2014). Thus, this research explores in detail how decisions are made about international student admissions, which policy makers (governmental or institutional) are responsible for the decisions and the extent to which research is considered in making such decisions.

\section{Participants and methodology}

\section{Participants}

Employing a purposeful sampling strategy, participants were selected from the five Flemish universities and at the department of education. In November 2016, the vice-deans and educational directors of the five Flemish universities (University of Leuven, Ghent University, University of Antwerp, University of Brussels, University of Hasselt) were asked to identify the members of staff tasked with determining the admission criteria for international students. Consequently, all participants at the university level were senior members of staff, directly responsible for the admission policy at their institution.

Because the policies at the Flemish universities are partly determined by a Flemish decree (Vlaamse Regering, 2013), senior policy makers at the government level were also recruited and participated, using the same procedure. The head of higher education policy 
within the department of education identified the civil servants specifically responsible for guidelines concerning university admission.

All policy makers who had been identified as the key actors agreed to participate, and as such the research population $(N=15)$ equals the full real-world population. In other words: every person who was responsible for university admission policy in Flanders at the time of data collection participated in this study. For the sake of anonymity, all respondents will be referred to using a code: U1 through U12 for policy makers at university level, and G1 through G3 for policy makers at governmental level. Since there are at least two participants for each institution, the quotes in this article cannot be attributed to any one participant in particular.

\section{Data collection and coding}

All interviews were held at the respondents' workplace, and all but one lasted over one hour (Median duration: 74.5 minutes). Respondents who worked at the same institution were interviewed together. Every interview was structured around three central components. First, the respondents were asked to explain how the university entrance policy regarding international students is determined. Next, every university entrance requirement in place at a given institution was discussed. In the third and final part of the interview - which goes beyond the scope of this article - the researcher gave an overview of a number of relevant research findings.

Since every institution's admission policy was based on the codex, most admission policies largely correspond, which allowed us to directly compare the reasoning behind the policy at different institutions. Respondents were prompted to explain the nature, purpose, and perceived effectiveness of each language requirement. The appendix shows an anonymized interview protocol, translated from Dutch. The actual protocols used were more concrete, and directly referred to the policy texts.

Each interview was audio recorded and transcribed by the first author. Before the first round of coding, the transcripts were checked for accuracy and amended if necessary. The transcriptions were analyzed using a directed approach (Hsieh \& Shannon, 2005), a variation on an priori coding scheme. Coding was done in a structured way using NVivo 11 for Mac, and relying on a coding tree (Table 4) that consisted of three main branches, based on an established theory (Potter \& Levine-Donnerstein, 1999), in this case Fischer's policy analysis 
framework. The first two branches focus on how policy is made and enacted (relying on policy evaluation literature, e.g., Jann \& Wegrich, 2007) and the third branch investigates the policy makers' beliefs about the admission requirements.

[Table 4 around here]

In the first round of coding, the data were coded for one of these branches. In the second round, subcategories ("nodes") were assigned to allow for a more refined analysis, and in a third round data that had not been coded was checked to see whether it represented a previously unestablished coding category. Since both the interviews and the coding scheme relied on the same structure and source, this was not the case.

\section{Results \\ How is the admission policy made at government level?}

At governmental level, policy is adjusted or reconsidered when universities or political stakeholders raise concerns. A procedure of policy adjustment begins only if a university issues a complaint or makes a concrete and successful proposal for policy adjustment. This is a process of tweaking and adjustment that is not normally founded on research, but rather on political compromise. The respondents at governmental level explained the general process of how policies are changed. From the quote below it is clear that a proposition for a policy change, whether based on empirical research or not, needs to be acceptable to all the parties in government. Regardless of its intrinsic worth, a policy measure will only pass when government parties can agree on it:

Int. Which elements can impact policy change?

G2 If we receive a request or an advice for a policy change, we take it to the cabinet. Based on that we decide on whether or not to proceed [...]

Int. On the basis of what do you decide?

G2 On the basis of what is politically feasible at a given moment. What really needs to be done, or what do they really want to achieve? These types of considerations. After that we enter a process of negotiations, talks between 
different cabinets. And in the end the initial proposition can look very differently.

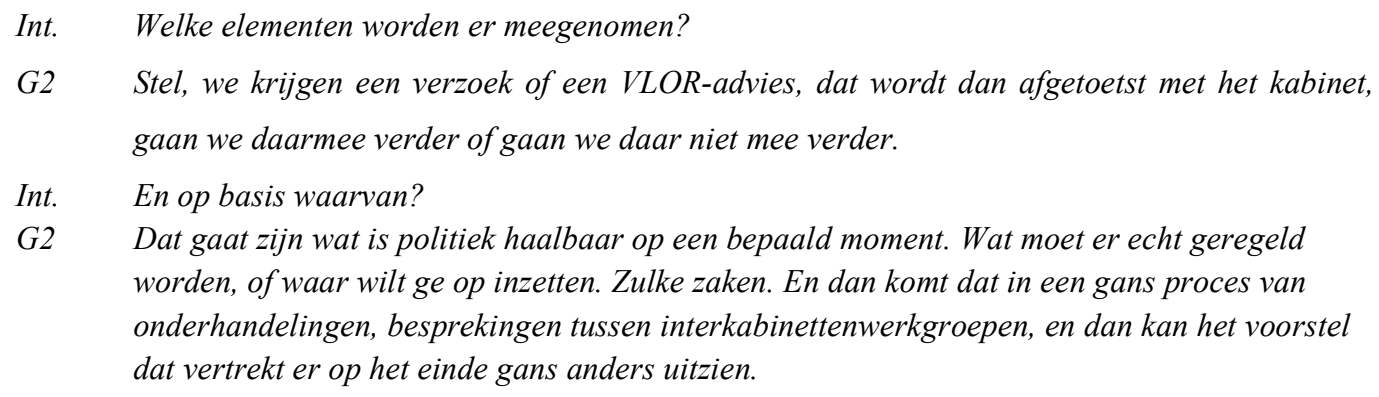

The three respondents from the government level did not spontaneously address the role of empirical research in shaping or adjusting policy measures. When asked about it, they stated that in policy-making, the impact of empirical research is typically rather minimal, compared to the impact of political compromise. The conversation above refers to general practice and not necessarily language admission. According to the participants, empirical evidence would not discourage policy makers from writing the policy that they want. The conversation below could be paraphrased as: policy makers often use only the research that suits their agenda, and research alone would not be sufficient ground to alter the course of intended policy.

G3 Actually, research is often used to reach a certain goal. That's right, isn't it?

G2 It is.

G3 If they want something to become policy

G1 But it's not like we would do or order a scientific study because we wanted to change policy

G2 It could happen that a recommendation for a policy change is based on a scientific study

Int. Would research alone be sufficient to lead to a change in policy?

G2 There are always political negotiations, and all stakeholders are involved. No, it's not like "here's the research outcome, let's change policy".

G3 It's not because research shows something, that it will be part of the policy.

G3 Eigenlijk is het dikwijls wel een beetje gericht dat men zo een onderzoek gaat gebruiken. Dat is toch wel zo? 
G2 Dat is.

G3 Als men graag iets wil, in de regelgeving.

G1 Maar 't is niet omdat we iets willen wijzigen dat we daarom een wetenschappelijke studie erover doen of laten doen.

G2 Maar het zou wel kunnen dat een advies gebaseerd is op een wetenschappelijke studie.

Int En worden er soms beslissingen genomen louter obv wetenschappelijke resultaten?

G2 Er zijn altijd politieke onderhandelingen en overleg en alle stakeholders worden betrokken. Nee. Het is dus niet van daar is een resultaat, hop, regelgeving wordt aangepast

G3 Het is niet omdat onderzoek iets aantoont dat dat ook in beleid komt.

The quote above shows the policy-makers' beliefs about research and policy. Collectively, they point out that policy advice may be based on existing studies, but the actual policy decisions are a matter of politics rather than research.

As the evidence shows, processes of policy revision and adjustment have not taken place in the context of university admission of international L2 students. No requests for policy change have been put forward since the codex was last amended in 1994. Instead, it has "simply been reused" (G2), because nobody has raised a complaint or suggested a policy change in 23 years. Since the codex has been in use for over twenty years without being considered for revision, the government officials interviewed did not know what it was based on:

G1 We have been working here for a pretty long time, but this rule has been around longer $[\ldots]$ To us the rules have always seemed logical. Actually, they have never been questioned in all those years.

G1 We werken hier nu toch al tamelijk lang, maar die regel is er al veel langer [...] Ons leken de regels altijd logisch. En ze zijn eigenlijk in al die jaren nooit in vraag gesteld.

Since the codex only has advisory status, the static nature of governmental policy regarding university admission language requirements does not prevent universities from designing and implementing their own requirements. The real locus of change and responsibility thus lies at the level of universities, which is the focus of the following section.

How is the admission policy made at university level? 
The mechanics of how policy is made at the institutional level are not dissimilar from the governmental level. All institutions have based their requirements on the codex, and have made amendments to the framework it provides. As is the case at the governmental level, changes to the university admission language requirements depend on faculties or professors raising concerns or suggesting changes. After an issue has been raised, at least two councils or boards will decide on whether and how to act on it. At two universities the language requirements are discussed annually, but at the other three the admission policy for international L2 students was not routinely considered or adjusted.

Because universities are under no legal obligation to follow the codex, most institutions have created exemptions for certain students. At four out of five Flemish universities, certain students at the master's or postgraduate level can be exempted from the language requirements, but the rationale given for these exemptions is not rooted in research, and appears to be determined by more practical considerations, such as budgets, student numbers, or requests by powerful faculty members. No respondent referred to empirical data as a reason for adjusting the language requirements for specific programs. Instead, policy makers at all universities were influenced to make changes in the language requirements by both internal and external factors. Internally, the policy was influenced primarily by pressure coming from faculties, professors or deans. The external factors could be anything from demographical shifts to policy decisions at other universities, or in other countries.

Often, exemptions from language requirements are the result of internal pressure from specific faculties or programs, who use the requirements to manage how many international students can enroll in a given year. Respondents at all universities explained that it was simply not possible to design policy without accounting for the views and aims of powerful internal stakeholders such as chancellors and deans:

U2 Most likely we will never be able to implement very big changes but we are able to make recommendations supported by research [...] in the end it's a game of politics

U2 Heel drieste veranderingen zullen we er wellicht nooit door krijgen maar ik denk wel dat we zeker gestaafd met onderzoek toch wel aanbevelingen kunnen doen. [...] Dat is eigenlijk een politiek spel. 
U6 Is everybody happy with these exemptions? I have to be honest: no. But it has been decided that they want to continue to allow for this exemption

U6 Is iedereen daar even gelukkig mee? Ik moet daar eerlijk in zijn: nee. Maar het is iets dat beslist is geweest, waar men een uitzondering voor wil blijven toestaan.

In other cases, exemptions were not clearly stated in the admission policy texts, but the requirements were vague enough to create leeway when certain professors wanted to admit a specific student. Respondents at three universities explicitly stated that the language requirements were intentionally vague. "I think there are supposed to be small flaws in the system", U2 stated, before referring to instances of professors admitting students who did not meet the language requirements. She went on to explain how she tries to follow the admission rules for all students, but with some influential faculty, this is not always possible: "I try to stand my ground then [...] and sometimes I can, sometimes I can ' $t$ '.

Sometimes, events that are beyond the control of a university may prompt policy changes. For example, in 2012 one university had eliminated all language requirements for international L2 students. In 2015 the language requirement was reinstated, because the university was suddenly faced with an influx of German students. From one year to the next, 
more than half of the freshmen in psychology and biomedical sciences were German students:

U7 These German students were coming to our university because of a reform in the secondary education system in their country. [...] These people were looking for solutions, and ended up with us. And then we needed to fix that situation.

U7 De Duitstalige studenten die dan naar hier komen door een hervorming in het secundair onderwijs daar. [...] Ja die personen zoeken uitwegen, en ja komen dan bij ons terecht. En ja ge moet daar dan iets aan doen.

Another external influence is the policy adopted by nearby universities. In order to match the policy of a larger university nearby, one institution lowered the required entrance level from $\mathrm{C} 1$ to $\mathrm{B} 2$, since they did not want to be stricter than their competitor and lose students over it.

How is policy effectiveness monitored?

All respondents at the institutional level defined the goal of the university admission policy similarly: To select students who have a sufficient level of language proficiency to be able to attend a Dutch-medium university program. When asked to comment on the effectiveness of the policy measures to reach the policy goal however, they were hesitant. No respondent claimed that the language requirements at their university were effective tools to reach the policy goal. Two primary reasons for this emerged.

One reason was the lack of a precise means to measure policy effectiveness. All institutions lacked clear statistics of the amount of international L2 students who study in Dutch, and no institution had a policy in place to follow up, trace, or monitor the well-being or academic progress of these students. For Flemish students with a migrant background or for international students who take courses in English, such follow-up programs do exist. For one respondent, the reason for this discrepancy was quite clear: "I think this group of students is too small and hard to reach and that's why it doesn't happen (U2)"'.

The second reason was the policy makers' perception of their professional responsibility. No policy makers in this study considered themselves responsible for 
designing an efficient system; instead, they described their job in terms of making compromises work:

U3 Certain programs ask us to be less strict cause they like having many students. Other programs tell us they have students who don't understand what is being said in class, even though they had the required certification. [...] So the comments we get go both ways. Now, after a few years, we feel that the requirements we have are a compromise between both positions.

U3 Er zijn opleidingen die zeggen ge moet zo streng niet controleren. Omdat ze graag veel studenten hebben. En langs de andere kant hebt ge ook opleidingen die zeggen we hebben hier studenten die niet begrijpen wat er gezegd wordt. Maar dus wel de nodige attesten hadden [...] Dus de opmerkingen die we vanuit de opleidingen krijgen gaan de twee kanten uit, en doorheen de jaren hebben we wel zoiets dat deze regeling het compromis is tussen de twee.

Policy makers - both at the level of government and at the level of institutions - did not know whether their policy measures were conducive to attaining the policy goal. One policy maker explicitly stated that he felt the measures were not effective, others $(n=5)$ voiced their doubts, but most $(n=9)$ admitted they had no idea because they had not investigated policy effectiveness, and did not really see how they could go about it:

U2 Honestly, I have my doubts regarding the effectiveness of our policy for everybody. Part of what we lack at the admission office, is post-admission follow-up. And that is a huge lack, because it means that we simply have no idea what happens to these people after admission.

U2 Ik heb daar eerlijk gezegd mijn twijfels bij. Of dat voor iedereen even effectief is. Een deel van wat wij hier missen als admission office is dat onze opvolging stopt bij het moment dat iemand ingeschreven is. En dat is een groot gemis omdat we op die manier eigenlijk hebt ge eigenlijk geen idee van wat is de uitstroom, wat doen die mensen.

What is the rationale behind the language admission requirements? 
None of the respondents had fundamentally considered the rationale behind the language requirements at their institution. They were focused on maintaining a compromise that was acceptable to the important stakeholders, rather than on the empirical soundness of their beliefs. In this section we will discuss the rationale behind the B2 level and behind the language admission requirements that are shared by all universities: a STRT or ITNA certificate, having completed one year at a Dutch-medium secondary school, and having completed one year at a Dutch-medium university.

At every university, the default entrance level is B2, but the reasons given for using that level seldom referred to empirical research on how this level predicts student success in the university. In fact, determining the required entrance level appeared to have less to do with standard setting or scientific procedures than with meeting the demands of influential individuals or departments within the institution: "When a professor objects, I try to hold my ground, and sometimes I can, sometimes I can 't' (U2). At one university, programs can now decide on the proficiency level they choose for acceptance. Throughout all interviews, the rationale for this policy was unconvincing: "Because B1 is too little, and C1 is too much" (U3). This policy originates more from practical considerations - a lower level of proficiency as a requirement supports higher enrollments - than from needs analysis.

U5 We used to have only B2 as a minimum requirement, but when translation studies became part of the university, they wanted to keep the $\mathrm{C} 1$ requirement they had had before. Then, the faculty of Arts said they wanted C1 as a minimum requirement too [...] now every faculty can decide whether they want $\mathrm{B} 2$ or $\mathrm{C} 1$. At one point it became part of the policy. I don't know when, but probably in 2013 , to facilitate the acquisition of Translation Studies.

U5 Dus vroeger hadden we eigenlijk enkel minimum B2 maar toen met de inkanteling van de vertaler tolken - die gebruikten C1 en die wilden dat ook behouden. En dan zijn Taal en Letterkunde daar op gesprongen om te zeggen ja voor ons geldt eigenlijk hetzelfde. Wij willen het minimum naar C1. [...] Nu kan elke opleiding beslissen welk niveau ze willen B2 of C1. Dat is er ooit eens in gekomen. Ik weet niet historisch hoe lang het er al in staat. Ik denk naar aanleiding van die integratie in 2013 om dat mogelijk te maken.

Regarding STRT and ITNA, the two B2 tests that are accepted at every Flemish university, all respondents at all universities agreed that the tests are legally equivalent. In 
other words: both lead to the same outcome. Six respondents at three universities also assumed level equivalence between the two tests, but never with an empirically-founded rationale: "we consider them equivalent. I don't know why. Probably because both are at the B2 level according to something or somebody" (U2). Respondents at other institutions noted that for them, the legal perspective was the only one that mattered and as such the question of level equivalence had not occurred to them yet. The quote below illustrates that point of view, and indicates how ad-hoc decisions can become policy.

U3 We don't actually wonder about equivalence [...] What matters for us is that we have all the documents we need for registration. Some students will present a document that is not on our list of accepted certification. In that case, we check it, ask our language center for advice [...] That's how things get added to the language requirements. But if they are equivalent? [...] We accept both as proof of B2.

U3 Dat vragen we ons eigenlijk niet af [...] Bij ons komt het er op neer we moeten alles hebben om die student te kunnen inschrijven. Soms komen ze met iets af dat er niet in staat. Dan wordt dat bekeken, wordt er soms advies gevraagd aan een talencentrum [...] T is op die manier dat er soms zaken aan toegevoegd worden. Maar of die zaken die er in staan het equivalent zijn van mekaar? [...] We aanvaarden beiden als een bewijs van $B 2$.

Only two respondents expressed certainty that the requirement of having successfully attended one year at a Dutch-medium secondary school would be reliable proof of B2 proficiency. This requirement stems from the codex and has not been altered in any university admission policy. On the other hand, upon questioning, no respondent assumed that this requirement would guarantee that prospective students have sufficient language proficiency. The following discussion between policy makers shows quite clearly that the reasoning behind admission requirements may bypass linguistic arguments in favor of pragmatic ones. Note that the practical argument quoted below does not identify any system that will help students to improve their language proficiency but instead simply posits that it may occur. 
U5 It's always been in there [...] You could doubt this requirement, probably [...] I have always wondered if we could make it more strict but I know there would be a lot of internal resistance if we did that.

U6 No! I think we should accept the guidelines in the decree, and not make them stricter. Let's give [students] a chance if we can. Who knows, their language proficiency may improve at university.

U5 Dat is altijd zo geweest [...] Daar kan je vragen bij stellen natuurlijk. [...] Ja. Dat heb ik mij persoonlijk altijd afgevraagd: kunt ge dat strenger maken? Maar ik weet dat er hier in de instelling redelijk wat weerstand zou ontstaan als je de regels zou verstrengen.

U6 Nee. Ik vind gewoon als het decretale richtlijnen zijn dat je die moet aanvaarden en dat je die niet nog strenger moet gaan maken. Ik heb dan zoiets van als het kan, laten we hen dan ook de kans geven. En wie weet kunnen ze ook nog tijdens hun opleiding hun taal verbeteren he.

Lastly, all respondents agreed that students who had already completed one year at a Dutch-medium university have offered adequate proof of possessing a sufficient level of language proficiency. This was the one requirement that all participants had the most confidence in.

\section{Discussion}

The interview data suggest that the Flemish university admission policy does not rigidly follow a linear or cyclical logic, and it does not rely on routine evaluation to determine its effectiveness (Jann \& Wegrich, 2007). Instead, policy makers report that policies are adjusted when problems need to be solved, or when important stakeholders demand change. At the governmental level, no language testing experts had been consulted since the start of the policy measures in 1994. At universities too, the policy had never been evaluated by outside experts.

This study confirmed that the university admission policy is the result of a series of pragmatic rather than empirical, systematic or logical decisions (Ball, 2015). Universities follow the recommendations of the governmental decree, except when they do not. They may sometimes use empirical data, but at other times may not. Tellingly, no respondent gave empirically founded arguments to argue why specific language requirements had been adjusted. In reality, these requirements were used to flexibly control student access to specific programs, depending on the current needs or challenges. At one university, the decision to first dismiss and later reinstate language requirements was driven entirely by practical 
considerations regarding the student population. Similarly, another institution lowered the requirement from $\mathrm{C} 1$ so they would not lose students to competing universities. Additionally, quite a few respondents acknowledged that certain programs have no language requirements, simply because professors do not want to lose student enrollment because of them.

If policy is essentially about the use of power, as Wilson (2006) argues, then policymaking is about making compromises that account for the diverging interests of different parties. The same dynamic is demonstrably present at Flemish universities, where program directors are important drivers of the Flemish university admission policy. This may explain why some admission language requirements for international L2 students have remained unchanged and unchallenged for years: International L2 students studying in Dutch are too small a group to be powerful, and too dispersed to be noticed by a stakeholder. Moreover, if the policy appears to be working, then there is no impetus to change it.

The relevance of this study exceeds the beliefs and practices of one specific context. This study shows that policy makers hold views regarding admission language requirements that may differ substantially from those held in the assessment community. No respondent believed that the admission system at their university was infallible. Nevertheless, most reported that the admission criteria served their purpose, not because they are empirically defensible, but because they were an acceptable compromise. The interview data largely confirm that policy is more focused on problem-solving rather than on proactively implementing of systemic improvements (Ball, 2015). Consequently, as this research shows and consistent with and policy analysis literature (e.g., Howlett \& Giest, 2013; Jann \& Wegrich, 2007), empirical evidence alone rarely convinces policy makers to make policy changes.

A problem often looks different when viewed from different perspectives,and policy makers and researchers may develop very different solutions to the same issue (Goodin, Rein, $\&$ Moran, 2006). The current study showed policy makers as pragmatists. Researchers, on the other hand may not always account for real-world constraints or political strategies (e.g., Howlett \& Giest, 2013; Jann \& Wegrich, 2007). Language assessment literacy researchers, for example, may adhere to a view that is quite different from that of policy makers. Outlining assessment competency profiles that list the specific testing expertise that would be required of university admission officers (Taylor, 2013), does not appear to match the day-today reality of policy makers. Similarly, educating admission officers in matters of validity, in order to ensure that they can make informed individual decisions (O'Loughlin, 2013) may 
adhere to a somewhat idealistic view that is quite distant from the pragmatic one used by policy makers.

To have impact, linguists should be aware of this, and should develop a sense of policy literacy (Lo Bianco, 2014; Pill \& Harding, 2013). As Fulcher (2009) points out, “all growth, including economic development, comes from variety and innovation, not from uniformity and standardization" (Fulcher, 2009, p. 13). Therefore, proponents of LAL need to develop a system of innovation that will appeal to the decision-makers and their line of thinking. As [Author] (2014) found, many administrators in international student admissions and services lack deep knowledge about what large-scale assessments actually measure and might benefit from informed approaches to help them make decisions, presented in ways that account for their own professional backgrounds and the competing demands on their time and attention. Reaching out to these stakeholders in ways that appeal to arguments that matter to them might prove more effective than adhering to our perspective as language testing professionals. That does not mean that policy makers should not be informed about empirical results. The information should, however, meet their frame of reference and their day-to-day reality, rather than the researchers' ideals.

The results of this paper also suggest that language testers should revisit the ILTA Code of Ethics when developing tests and when communicating with users. As Principle 7 states:

Language testers in their societal roles shall strive to improve the quality of language testing, assessment and teaching services, promote the just allocation of those services and contribute to the education of society regarding language learning and language proficiency

Principle 7 is further annotated to include the points below:

Language testers shall be prepared by virtue of their knowledge and experience to advise those responsible for the provision of language testing services.

Language testers shall make clear that they do not claim (and are not seen to claim) that they alone possess all the relevant knowledge.

Thus, the ILTA Code of Ethics refers directly to the need for language test providers to help users understand their tests and the possible uses (and misuses) of them. The annotations also emphasize the need to advise users, and directly state that language testers do not "alone possess all the relevant knowledge." Therefore, working in collaboration with policy makers on language test selection and required scores for entry is inherent in the ILTA Code of Ethics and must be adhered to by users. 
In the context of this study, that approach has led to a promising evolution: after receiving an invitation that focused on how empirical data could improve both policy effectiveness and stakeholder satisfaction, all university admission policy makers in Flanders agreed to meet for the first time, and to jointly discuss and potentially revise and streamline their admission policy. As a direct consequence of this meeting, three out of five universities are making or preparing policy changes. One major university is looking into revising the B2 requirement in favor of one more consistent with the real-world demands, another institution is working on a monitoring system for international students' progress by assigning them a specific status upon registration, and a third has pledged to focus on the well-being of international students, and to create a platform for them to voice their needs. These results suggest that language assessment literacy and outreach have the potential to inform and influence future policy.

\section{LIMITATIONS}

Like any study that examines a new population, the current study has a number of limitations. Because policy makers are limited in what they can do by an invisible network of interests and power politics, these meetings may not have the impact that researchers may wish, even when results are communicated appropriately and clearly. This is because the responsibility for a policy may reside with the policy maker, but the power to change it rests in many hands. The limitations are described below, along with ways to address them in the future.

First, by focusing on those responsible for policy at the highest level of university admission, we have necessarily restricted the information collected to a small, elite group. On the one hand, this population has considerable influence and power to make and enforce decisions and thus their beliefs about language assessment policy are most likely to influence, even dictate, policy. On the other hand, such stakeholders rarely make concrete decisions on the ground. Moreover, they seldom act independently and may rely on feedback from a variety of stakeholders from within and outside the university system. Thus, while the beliefs of this group are important, future research should also investigate the beliefs of stakeholders who advise and influence the final policy makers. Such research could result in a better understanding not only of who the potential decision-makers are but also how and when they can influence policy. 
Similarly, while this paper has suggested that testing experts should inform policy makers, subsequent research could focus on both what language testing experts believe about policy makers (and other stakeholders) and how to first listen to such stakeholders and then work to educate them about language policies. As Author (2013) points out, language testing experts may bring their own biases and preferences about language testing when working on assessment literacy projects. For example, language testing experts may themselves have biases about specific aspects of language assessment or about the roles of specific stakeholders. Such biases have the potential to interfere with a true exchange of ideas and development of language assessment literacy. Just as the field conducts research on others' beliefs, perhaps it is time to explore the beliefs of language testing professionals in order to unearth biases and impediments to collaboration.

Finally, this study is limited to just one European country. Before robust generalizations can be made, similar studies should be undertaken in different contexts. The publication of such studies may help to improve policy makers' language assessment literacy and language testers' policy literacy. The methodology, results and outcomes of the current study could serve as a starting point for such studies in additional contexts.

\section{References}

ACTFL. (2016). Assigning CEFR ratings to ACTFL assessments. Washington, D.C.: American Council On The Teaching Of Foreign Languages.

Baker, B. A. (2016). Language assessment literacy as professional competence: The case of Canadian admissions decision makers. Canadian Journal of Applied Linguistics, 19(1), 63-83.

Baker, B. A., Tsushima, R., \& Wang, S. (2014). Investigating language assessment literacy: Collaboration between assessment specialists and canadian university admissions officers. Language Learning in Higher Education, 4(1), 137-157.

Ball, S. J. (2015). What is policy? 21 years later: reflections on the possibilities of policy research. Discourse: Studies in the Cultural Politics of Education, 36(3), 306-313.

Ball, S. J., Maguire, M., \& Braun, A. (2012). How Schools Do Policy: Policy Enactments in Secondary Schools. New York: Routledge. 
Beleidscel Diversiteit en Gender. (2016). Diversiteit aan de UGent: de instroom van kansengroepen in cijfers. Ghent: Ghent University.

Council of Europe. (2001). Common European Framework of Reference for Languages: Learning, Teaching, Assessment. Strasbourg: Council of Europe.

De Wachter, L., \& Heeren, J. (2013). Eerste analyses taalvast. Internal policy document. Leuven: KU Leuven.

Departement Onderwijs en Vorming. (2015). Taalverslag academiejaar 2013-2014. Departement Onderwijs en Vorming. Afdeling Hoger Onderwijs en Volwassenenonderwijs. Retrieved from www.Vlaanderen.be, October 232016.

Fischer, F. (2007). Deliberative policy analysis as practical reason: integrating empirical and normative arguments. In F. Fischer \& G. J. Miller (Eds.), Handbook of Public Policy Analysis: Theory, Politics, and Methods (pp. 223-236). Boca Raton: CRC Press.

Fulcher, G. (2009). Test use and political philosophy. Annual Review of Applied Linguistics, 29, 3-20. Fulcher, G. (2012). Assessment Literacy for the Language Classroom. Language Assessment Quarterly, 9(2), 113-132.

Ghent University. (2016, May 13). Education and Examination Code academic year 2016-2017. Retrieved September 30, 2016, from http://www.ugent.be/student/nl/studeren/regelgeving Goodin, R. E., Rein, M., \& Moran, M. (2006). The public and its policies. In M. Moran, M. Rein, \& R. E. Goodin (Eds.), The Oxford handbook of public policy (pp. 3-39). Oxford: Oxford University Press.

Grin, F. (2003). Language policy evaluation and the European charter for regional or minority languages. New York: Palgrave Macmillan.

Hawkey, R. (2006). Teacher and learner perceptions of language learning activity. Elt Journal, 60, 242-252.

Howlett, M., \& Giest, S. (2013). The policy-making process. In E. J. Aral, S. Fritzen, M. Howlett, M. Ramesh, \& X. Wu (Eds.), Routledge handbook of public policy (pp. 17-28). London \& New York: Routledge. 
Hsieh, H.-F., \& Shannon, S. E. (2005). Three Approaches to Qualitative Content Analysis.

Qualitative Health Research, 15(9), 1277-1288.

ILTA. (2000). Code of ethics. Retrieved June 3, 2014, from www.iltaonline.com.

Inbar-Lourie, O. (2008). Constructing a language assessment knowledge base: A focus on language assessment courses. Language Testing, 25(3), 385-402.

Inbar-Lourie, O. (2017). Language Assessment Literacy. In E. Shohamy, I. Or, \& S. May (Eds.), Language Testing and Assessment (pp. 257-270). New York: Springer.

Jann, W., \& Wegrich, K. (2007). Theories of the Policy Cycle. In F. Fischer \& G. J. Miller (Eds.), Handbook of Public Policy Analysis: Theory, Politics, and Methods (pp. 43-62). Boca Raton: CRC Press.

KU Leuven. (2016, April 28). Onderwijs- en examenreglement 2016-2017. Retrieved September 30, 2016, from https:/www.kuleuven.be/onderwijs/oer/2016

Lejano, R. P. (2007). Postpositivism and the policy process. In F. Fischer \& G. J. Miller (Eds.), Handbook of Public Policy Analysis: Theory, Politics, and Methods (pp. 43-62). Boca Raton: CRC Press.

Lo Bianco, J. (2001). Policy Literacy. Language and Education, 15(2-3), 212-227.

Lo Bianco, J. (2014). Dialogue between ELF and the field of language policy and planning. Journal of English as a Lingua Franca, 3(1), 197-213.

Lo Bianco, J. (2017, May). Language policy and social cohesion. Presented at the ALTE 6th international conference, Bologna.

Malone, M. E. (2013). The essentials of assessment literacy: Contrasts between testers and users. Language Testing, 30(3), 329-344.

Malone, M. E., \& Montee, M. (2014). Stakeholders’ Beliefs About the TOEFL iBT® Test as a Measure of Academic Language Ability. ETS Research Report Series, 2014(2), 1-51.

McNamara, T. (2009). Language tests and social policy: A commentary. In G. Hogan-Brun, C. MarMolinero, \& P. Stevenson (Eds.), Discourses on language and integration (pp. 153-164). Amsterdam: John Benjamins Publishing. 
McNamara, T., \& Shohamy, E. (2008). Language tests and human rights. International Journal of Applied Linguistics, 18(1), 89-95.

O’Loughlin, K. (2011). The Interpretation and Use of Proficiency Test Scores in University Selection: How Valid and Ethical Are They? Language Assessment Quarterly, 8(2), 146-160.

O’Loughlin, K. (2013). Developing the assessment literacy of university proficiency test users. Language Testing, 30(3), 363-380.

Pill, J., \& Harding, L. (2013). Defining the language assessment literacy gap: Evidence from a parliamentary inquiry. Language Testing, 30(3), 381-402.

Potter, W. J., \& Levine-Donnerstein, D. (1999). Rethinking validity and reliability in content analysis. Journal of Applied Communication Research, 27(3), 258-284.

Rea-Dickins, P., Kiely, R., \& Yu, G. (2007). Student identity, learning and progression: The affective and academic impact of IELTS on "successful" candidates. IELTS Research Reports, 7.

Smith, H. A., \& Haslett, S. J. (2007). Attitudes of tertiary key decision-makers towards English language tests in Aotearoa New Zealand: Report on the results of a national provider survey. IELTS Research Reports, 7, 13-57.

Taylor, L. (2009). Developing assessment literacy. Annual Review of Applied Linguistics, 29, 21-36.

Taylor, L. (2013). Communicating the theory, practice and principles of language testing to test stakeholders: Some reflections. Language Testing, 30(3), 403-412. https://doi.org/10.1177/0265532213480338

Toulmin, S. (2003). The Uses of Argument. Updated Edition. (Updated edition). Cambridge, U.K. ; New York: Cambridge University Press.

Universiteit Antwerpen. (2016, April 12). PROCEDURE PROC/ADOND/001.1. Retrieved September 30, 2016, from www.uantwerpen.be.

Universiteit Hasselt. (2016). Taalvoorwaarden. Retrieved January 29, 2016, from www.uhasselt.be/Taalvoorwaarden.

Van Avermaet, P., \& Pulinx, R. (2013). Language Testing for Immigration to Europe. In A.J. Kunnan (Ed.). The Companion to Language Assessment. Walden, MA: John Wiley \& Sons, Inc. 
Van den Bosch, K., \& Cantillon, B. (2006). Policy impact. In M. Moran, M. Rein, \& R. E. Goodin (Eds.), The Oxford handbook of public policy (pp. 296-319). Oxford: Oxford University Press.

Van Gorp, K., Luyten, L., De Wachter, L., \& Steemans, S. (2014). A concurrent validity study of two academic placement tests. Presented at the ALTE 5th International Conference, Paris.

Van Houtven, T., Peters, E., \& El Morabit, Z. (2010). Hoe staat het met de taal van studenten? Exploratieve studie naar begrijpend lezen en samenvatten bij instromende studenten in het Vlaamse hoger onderwijs. Levende Talen Tijdschrift, 11(3), 29-44.

Van Oers, R. (2014). Deserving Citizenship. Citizenship Tests in Germany, the Netherlands and the United Kingdom. Leiden \& Boston: Brill.

Vedung, E. (2013). Six models of evaluation. In E. J. Aral, S. Fritzen, M. Howlett, M. Ramesh, \& X. Wu (Eds.), Routledge handbook of public policy (pp. 387-400). London \& New York: Routledge.

Vlaamse Regering. Besluit van de Vlaamse Regering tot codificatie van de decretale bepalingen betreffende het hoger onderwijs, Pub. L. No. B.S.27/02/2014, § Deel 2. Hoofdstuk 8. (2013). Retrieved from http://data-onderwijs.vlaanderen.be/edulex/document.aspx?docid=14650\#44

Vrije Universiteit Brussel. (2014). Onderwijs- en examenreglement 2014-2015. Retrieved October 25, 2016, from www.vub.ac.be.

Wollmann, H. (2007). Policy evaluation and evaluation research. In F. Fischer \& G. J. Miller (Eds.), Handbook of Public Policy Analysis: Theory, Politics, and Methods (pp. 393-402). Boca Raton: CRC Press. 
Table 1. Fischer's argumentative model for policy analysis: discursive phases.

\begin{tabular}{|c|c|c|}
\hline Discursive phase & Focus & Goal \\
\hline Program verification & Effectiveness & $\begin{array}{l}\text { Determining whether a policy successfully } \\
\text { tackles the perceived problem }\end{array}$ \\
\hline Situational validation & Relevance & $\begin{array}{l}\text { Examining the wider context of a policy as well } \\
\text { as the assumptions held by policy makers about } \\
\text { the perceived problem }\end{array}$ \\
\hline Systems vindication & Societal value & $\begin{array}{l}\text { Investigating the societal value of a policy, as } \\
\text { well as its impact and (unanticipated) } \\
\text { consequences }\end{array}$ \\
\hline Ideological choice & Policy ideals & $\begin{array}{l}\text { Determining whether the ideological foundations } \\
\text { of a policy allow for rational decision-making }\end{array}$ \\
\hline
\end{tabular}


Table 2. International students at the five Flemish universities (2015-'16)

\begin{tabular}{lll} 
& Student population & International students \\
\cline { 2 - 3 } University of Leuven & 41.500 & $19 \%$ \\
Ghent University & 41.000 & $11 \%$ \\
University of Antwerp & 20.000 & $14 \%$ \\
University of Brussels & 11.000 & $20 \%$ \\
University of Hasselt & 6.000 & $9 \%$ \\
\hline
\end{tabular}


Table 3. Correspondences between ACTFL and CEFR levels on productive skill tests

\begin{tabular}{ll} 
ACTFL & CEFR \\
\hline Superior & C2 \\
Advanced High & C1 \\
Advanced Mid & B2.2 \\
Advanced Low & B2.1 \\
Intermediate High & B1.2 \\
Intermediate Mid & B1.1 \\
Intermediate Low & A2 \\
Novice High & A1 \\
&
\end{tabular}


Table 4. Data coding categories

\begin{tabular}{|c|c|c|}
\hline Branch & Topic & Node \\
\hline 1 & Policy-making process & impacting variables, empirical foundation \\
\hline 2 & Policy enactment & goal, effectiveness, post-admittance policy \\
\hline 3 & Policy makers' beliefs & $\begin{array}{l}\text { - The B2 requirement; } \\
\text { - The use of STRT and ITNA as equivalent tests; } \\
\text { - having completed one year at a Dutch-medium } \\
\text { secondary school; } \\
\text { - having completed one year at a Dutch-medium } \\
\text { university. }\end{array}$ \\
\hline
\end{tabular}




\section{Appendix. Interview protocol}

\section{Introduction of researcher, study, and participants}

1. Introduce researcher and study

2. Thank participants, explain their rights, and explain motivation to conduct the interview:

- To discuss the admission requirements at this university, how they have come to be, and how they are used in practice.

- To present a number of research findings that may be relevant to university admission policy makers

3. Participants introduce themselves, state their name, their job title, and their responsibilities.

\section{Part 1: Questions regarding the admission policy at university $\mathbf{x}$}

Policy-making:

- Please describe the chain of events involved in changing or making a new policy measure

- Who is involved in the policy-making process?

- What is the goal of the admission policy?

- Why is that the goal?

- How many students are affected by the language requirements and the testing policy?

Policy effectiveness:

- How effective do you think the policy measures are in reaching the policy goal stated earlier?

- Do you think every single measure is equally effective in reaching the policy goal?

- Which admission requirement do you think is the most / least effective in reaching the policy goal?

- Has the effectiveness of the policy been researched yet? 
- To what extent do the current policy measures rely on empirical research?

\section{Part 2: Discussion of admission requirements, as stated in the university's policy:}

For each requirement or policy measure, these questions should minimally be asked:

- Why do you have this requirement? Is it based on a specific assumption?

- Have you conducted any research to determine whether your assumption is correct?

- How sure are you that this requirement helps you to teach your policy goal?

- How sure are you that this requirement helps you to select people with B2 proficiency?

Regarding the chosen language tests and the B2 level, these questions should minimally be asked:

- Do L2 students with a B2 proficiency level have minimally acceptable competence?

- If the university requires a higher or a lower level, or no level altogether, for specific programs: why?

- Why did you decide to use B2 as the threshold level for university admission?

- Have you conducted any research to determine whether the B2 level is sufficient?

When exemptions are made, these questions should minimally be asked:

- Why do certain programs ask for exemptions?

- On what basis are they granted?

\section{Part 3: Research findings related to the main assumptions}

Introduce and explain the research findings pertaining to every primary policy assumption, e.g.: 
- B2 is an adequate threshold level to decide on international L2 students' access to a Dutch-medium university in Flanders.

- STRT and ITNA can be considered equivalent measures of B2 language proficiency.

- Students who have successfully passed one year at a Dutch-medium secondary school, will have B2 proficiency. 